\title{
Evaluation of sleep quality, psychological states and subsequent self-medication practice among the Bangladeshi population during Covid-19 pandemic
}

\author{
K.M. Yasif Kayes Sikdar ${ }^{\mathrm{a}, *}$, Juhaer Anjum ${ }^{\mathrm{b}}$, Nasiba Binte Bahar ${ }^{\mathrm{b}}$, Maniza Muni ${ }^{\mathrm{b}}, \mathrm{S}$. \\ M. Rakibul Hossain ${ }^{\mathrm{b}}$, Ashfia Tasnim Munia ${ }^{\mathrm{c}}$, A.S.M. Monjur Al-Hossain ${ }^{\mathrm{a}}$ \\ ${ }^{a}$ Department of Pharmaceutical Technology, Faculty of Pharmacy, University of Dhaka, Dhaka-1000, Bangladesh \\ ${ }^{\mathrm{b}}$ Department of Pharmacy, Faculty of Pharmacy, University of Dhaka, Dhaka-1000, Bangladesh \\ ${ }^{\mathrm{c}}$ Institute of Statistical Research and Training, University of Dhaka, Dhaka-1000, Bangladesh
}

\section{A R T I C L E I N F O}

\section{Keywords:}

COVID-19

Sleep quality

Psychological states

Self-medication

Drug dependency

\begin{abstract}
A B S T R A C T
Introduction: Due to the extended lockdown imposed for SARS-CoV-2 pandemic, many people have experienced problematic sleep patterns and associated health issues worldwide. This study was conducted to assess the sleep quality and psychological states of the Bangladeshi population during the COVID-19 pandemic, respondent's behavioral traits as well as psychological or sleep-related problems induced self-medication practice among the respondents, along with the probability of development of drug dependency.

Methods: The survey was conducted among 2941 respondents from 25th November 2020 to 4th December 2020 where the responses were analyzed by SPSS V22.

Results: 10-29.5\% experienced a significant degree of sleep problems whereas some experienced severe anxiety and depression. The associations between the behavioral traits and parameters concerning sleep quality, anxiety and depression showed 5\% level of significance in all cases. Self-medication practice of sleep aids during this pandemic was reported by $7.14 \%$ of the respondents, with a greater percentage belonging to the female or senior age group. Tendency to repeatedly self-medication was observed in $18.86 \%$ of this self-medicating populace, and a greater number of male $(10.26 \%)$ respondents displayed such tendency as opposed to their female $(8.6 \%)$ equivalents. However, $48.10 \%$ of the respondents reported perceptions of improved physical and/or psychological health following self-medication, and this trait was predominant in men (52.14\%).

Conclusion: Results showed a significant number of Bangladeshi populaces were suffering from psychological issues during this COVID-19 which also influenced a certain number of people towards self-medication practice where signs of drug dependency were observed in a significant number of respondents.
\end{abstract}

\section{Introduction}

The novel SARS-CoV-2 coronavirus outbreak that epi-centered in the Hubei Province of the People's Republic of China has spread to 220 countries in the world till $1^{\text {st }}$ May 2021. ${ }^{1}$ The first reported incidence of restricted social interactions due to this outbreak was observed in Wuhan on January 23, $2020^{2}$; and even after seventeen months (till May 2021) of the first detection of the virus, many countries are still following protocols of restrictions or limited social interactions. The first reported case of SARS-CoV-2 in Bangladesh, a developing country in South-East Asia, was observed on 7 March 2019. ${ }^{3}$ The country went into lockdown protocols on 26 March. ${ }^{3}$ There are 760,584 total confirmed cases and 11,510 total deaths in Bangladesh as of May 01, $2021 .^{4}$

SARS-CoV-2 has affected almost every aspect of life. The extended lockdown period, restricted social interactions and intensive preventive measures along with multi-factor induced stress have adversely affected the physio-psychological health of a large percentage of the general populace. $^{5-10}$ Sleep is an important parameter for physical and psychological soundness and a change in sleep pattern and habits can be an indicator of adverse physio-psychological changes. ${ }^{11}$ Region-specific studies regarding Covid-19 and its impact on sleep in the Bangladeshi populace have already been conducted, ${ }^{12}$ and an analysis of the data

\footnotetext{
* Corresponding author.

E-mail address: yasif@du.ac.bd (K.M.Y.K. Sikdar).
} 
Table 1

Socio-demographic characteristics of the respondents $(n=2941)$.

\begin{tabular}{|c|c|c|c|}
\hline \multicolumn{2}{|c|}{ Socio-demographic characteristics } & \multirow{2}{*}{$\begin{array}{l}\text { Frequency } \\
21\end{array}$} & \multirow{2}{*}{$\begin{array}{l}\text { Percent } \\
(\%)\end{array}$} \\
\hline Age & $\leq 15$ & & \\
\hline & $\overline{16}-25$ & 2009 & 68.3 \\
\hline & $26-35$ & 730 & 24.8 \\
\hline & $36-45$ & 122 & 4.1 \\
\hline & $46-55$ & 35 & 1.2 \\
\hline & $56-65$ & 22 & 0.7 \\
\hline & $\geq 66$ & 2 & 0.1 \\
\hline \multirow[t]{3}{*}{ Gender } & Male & 1861 & 63.28 \\
\hline & Female & 1078 & 36.65 \\
\hline & Prefer not to say & 2 & 0.07 \\
\hline \multirow[t]{2}{*}{ Current Residence } & Urban & 2262 & 76.9 \\
\hline & Rural & 679 & 23.1 \\
\hline \multirow[t]{7}{*}{ Profession } & Government Employee & 138 & 4.7 \\
\hline & $\begin{array}{l}\text { Non-government } \\
\text { employee }\end{array}$ & 371 & 12.6 \\
\hline & Teaching & 94 & 3.2 \\
\hline & Banker & 46 & 1.6 \\
\hline & Student & 1953 & 66.4 \\
\hline & Business person & 123 & 4.2 \\
\hline & Others & 216 & 7.3 \\
\hline Educational & Secondary & 205 & 7 \\
\hline \multirow[t]{6}{*}{ Qualification } & Higher secondary & 453 & 15.4 \\
\hline & Undergraduate & 1203 & 40.9 \\
\hline & Graduate & 473 & 16.1 \\
\hline & Post-graduate & 528 & 18 \\
\hline & M.Phil/PhD & 16 & 0.5 \\
\hline & Others & 63 & 2.1 \\
\hline
\end{tabular}

suggests an association between sleep quality degradation and several Covid-19 induced lifestyle changes; such as economic instability, changes in the work environment, fear and anxiety regarding infection, changes in sleep schedule etc. ${ }^{12}$ Electronic device and social media usage are factors that are associated with sleep quality which were revealed in several pre-Covid studies. ${ }^{16-20}$ However, though there have been possible changes in said factors due to Covid 19, the associations and impact are yet to be explored. Another key point to be noted that the Bangladeshi pharmaceutical retail market is not adequately regulated. As it is observed with similar inadequately regulated markets, ${ }^{13-15}$ the sale of non-OTC (over the counter) medication without proper prescriptions is persistent. With the recent increase in adverse sleep changes, a possible increase in unprescribed sleep medication sales might be observed.

Therefore, the present study aims to explore the significance of the associations between changes in sleep quality or psychosocial states (i.e. sleep disturbance, anxiety and depression) and the socio-demographic characteristics, caffeine intake, nicotine intake, electronic device usage and social media usage of an individual in lights of the ongoing pandemic. Though the influences of these factors on sleep quality, anxiety and depression have already been established, ${ }^{16-20}$ the pandemic has possibly brought about significant changes in said factors to justify a region-specific revisitation of the associations. The secondary aim is to find out if any changes have influenced unprescribed psychotropics usage in the Bangladeshi populace and if persisting, explore the possible development of drug dependency.

\section{Methods}

Design, measure and population of the study: This study was a cross-sectional questionnaire-based survey which was conducted among the mass population of Bangladesh. During the first wave of COVID-19, all the educational institutions were closed and a large number of offices were conducting their works from home. As peoples were staying at home, there had some chances of developing sleep disturbance and other psychological distresses among the populace. To find out these problems, the study was conducted from November 25, 2020 to
Table 2

Psychological parameters and behavioral patterns of the respondents ( $\mathrm{n}=$ 2941).

\begin{tabular}{|c|c|c|c|c|}
\hline \multicolumn{3}{|c|}{ Psychological parameters and behavioral patterns } & \multirow{2}{*}{$\begin{array}{l}\text { Frequency } \\
451\end{array}$} & \multirow{2}{*}{$\begin{array}{l}\text { Percentage } \\
15.33 \%\end{array}$} \\
\hline Sleep & \multirow{5}{*}{$\begin{array}{l}\text { Degree of } \\
\text { satisfaction with } \\
\text { sleep pattern }\end{array}$} & Very satisfied & & \\
\hline \multirow[t]{31}{*}{ Quality } & & Satisfied & 865 & $29.41 \%$ \\
\hline & & $\begin{array}{l}\text { Moderately } \\
\text { satisfied }\end{array}$ & 1044 & $35.50 \%$ \\
\hline & & Dissatisfied & 428 & $14.55 \%$ \\
\hline & & $\begin{array}{l}\text { Very } \\
\text { dissatisfied }\end{array}$ & 153 & $5.20 \%$ \\
\hline & \multirow{4}{*}{$\begin{array}{l}\text { Noticeability of } \\
\text { sleep problems }\end{array}$} & Not at all & 1096 & $37.27 \%$ \\
\hline & & A little & 1224 & $41.62 \%$ \\
\hline & & $\begin{array}{l}\text { Somewhat } \\
\text { much }\end{array}$ & 382 & $12.99 \%$ \\
\hline & & Very much & 239 & $8.13 \%$ \\
\hline & \multirow{4}{*}{$\begin{array}{l}\text { Worry about sleep } \\
\text { problems }\end{array}$} & Not at all & 1185 & $40.29 \%$ \\
\hline & & A little & 1249 & $42.47 \%$ \\
\hline & & $\begin{array}{l}\text { Somewhat } \\
\text { much }\end{array}$ & 366 & $12.44 \%$ \\
\hline & & Very much & 141 & $4.79 \%$ \\
\hline & \multirow{4}{*}{$\begin{array}{l}\text { Sleep problem } \\
\text { interfering with } \\
\text { daily functioning }\end{array}$} & Not at all & 777 & $26.42 \%$ \\
\hline & & A little & 1296 & $44.07 \%$ \\
\hline & & $\begin{array}{l}\text { Somewhat } \\
\text { much }\end{array}$ & 551 & $18.74 \%$ \\
\hline & & Very much & 317 & $10.78 \%$ \\
\hline & \multirow{5}{*}{$\begin{array}{l}\text { Difficulty in falling } \\
\text { asleep }\end{array}$} & None & 1081 & $36.76 \%$ \\
\hline & & Mild & 881 & $29.96 \%$ \\
\hline & & Moderate & 623 & $21.18 \%$ \\
\hline & & Severe & 270 & $9.18 \%$ \\
\hline & & Very severe & 86 & $2.92 \%$ \\
\hline & \multirow{5}{*}{$\begin{array}{l}\text { Difficulty staying } \\
\text { asleep }\end{array}$} & None & 1357 & $46.14 \%$ \\
\hline & & Mild & 764 & $25.98 \%$ \\
\hline & & Moderate & 522 & $17.75 \%$ \\
\hline & & Severe & 219 & $7.45 \%$ \\
\hline & & Very severe & 79 & $2.69 \%$ \\
\hline & \multirow{5}{*}{$\begin{array}{l}\text { Problems waking up } \\
\text { too early }\end{array}$} & None & 1469 & $49.95 \%$ \\
\hline & & Mild & 610 & $20.74 \%$ \\
\hline & & Moderate & 455 & $15.47 \%$ \\
\hline & & Severe & 257 & $8.74 \%$ \\
\hline & & Very severe & 150 & $5.10 \%$ \\
\hline \multirow[t]{8}{*}{ Anxiety } & \multirow{4}{*}{$\begin{array}{l}\text { Feeling nervous, } \\
\text { anxious or on edge }\end{array}$} & Not at all & 700 & $23.80 \%$ \\
\hline & & Several days & 1282 & $43.59 \%$ \\
\hline & & $\begin{array}{l}\text { More than } \\
\text { half the days }\end{array}$ & 285 & $9.69 \%$ \\
\hline & & $\begin{array}{l}\text { Nearly } \\
\text { everyday }\end{array}$ & 674 & $22.92 \%$ \\
\hline & \multirow{4}{*}{$\begin{array}{l}\text { Inability to stop or } \\
\text { control worrying }\end{array}$} & Not at all & 825 & $28.05 \%$ \\
\hline & & Several days & 1150 & $39.10 \%$ \\
\hline & & $\begin{array}{l}\text { More than } \\
\text { half the days }\end{array}$ & 312 & $10.61 \%$ \\
\hline & & $\begin{array}{l}\text { Nearly } \\
\text { everyday }\end{array}$ & 654 & $22.24 \%$ \\
\hline \multirow[t]{8}{*}{ Depression } & \multirow{4}{*}{$\begin{array}{l}\text { Little interest or } \\
\text { pleasure in doing } \\
\text { things }\end{array}$} & Not at all & 774 & $26.32 \%$ \\
\hline & & Several days & 1076 & $36.59 \%$ \\
\hline & & $\begin{array}{l}\text { More than } \\
\text { half the days }\end{array}$ & 389 & $13.23 \%$ \\
\hline & & $\begin{array}{l}\text { Nearly } \\
\text { everyday }\end{array}$ & 702 & $23.87 \%$ \\
\hline & \multirow{4}{*}{$\begin{array}{l}\text { Feeling down, } \\
\text { depressed or } \\
\text { hopeless }\end{array}$} & Not at all & 888 & $30.19 \%$ \\
\hline & & Several days & 870 & $29.58 \%$ \\
\hline & & $\begin{array}{l}\text { More than } \\
\text { half the days }\end{array}$ & 322 & $10.95 \%$ \\
\hline & & $\begin{array}{l}\text { Nearly } \\
\text { everyday }\end{array}$ & 861 & $29.28 \%$ \\
\hline Behavioral & Caffeine intake & Not used & 493 & $16.76 \%$ \\
\hline Traits & & Use increased & 1019 & $34.65 \%$ \\
\hline & & Use decreased & 369 & $12.55 \%$ \\
\hline & & $\begin{array}{l}\text { Remaining } \\
\text { same }\end{array}$ & 1016 & $34.55 \%$ \\
\hline & Nicotine intake & Not used & 2242 & $76.23 \%$ \\
\hline & & Use increased & 212 & $7.21 \%$ \\
\hline & & Use decreased & 231 & $7.85 \%$ \\
\hline & & $\begin{array}{l}\text { Remaining } \\
\text { same }\end{array}$ & 256 & $8.70 \%$ \\
\hline & Social media usage & less than $2 \mathrm{~h}$ & 304 & $10.34 \%$ \\
\hline & & $2-4 \mathrm{~h}$ & 884 & 30.06 \\
\hline
\end{tabular}

(continued on next page) 
Table 2 (continued)

\begin{tabular}{llll}
\hline Psychological parameters and behavioral patterns & Frequency & Percentage \\
\hline \multirow{4}{*}{ Using electronic } & $4-6 \mathrm{~h}$ & 750 & $25.50 \%$ \\
& $6-8 \mathrm{~h}$ & 483 & $16.42 \%$ \\
devices & more than 8 h & 520 & $17.68 \%$ \\
& less than 1 h & 288 & $9.79 \%$ \\
& $1-2 \mathrm{~h}$ & 633 & $21.52 \%$ \\
& $2-3 \mathrm{~h}$ & 565 & $19.21 \%$ \\
& $3-4 \mathrm{~h}$ & 391 & $13.29 \%$ \\
& $4-5 \mathrm{~h}$ & 337 & $11.46 \%$ \\
& $5-6 \mathrm{~h}$ & 246 & $8.36 \%$ \\
& More than 6 h & 481 & $16.35 \%$ \\
\hline
\end{tabular}

December 4, 2020. This survey was conducted through online social media like Facebook, WhatsApp, Viber, IMO etc. because face-to-face survey was difficult to maintain social distancing during the pandemic. The questionnaire was designed both in Bengali and English. Total 2941 respondents were participated in this survey. The respondent's socio-demographic characteristics were divided into age, gender, current residence, profession and educational qualification. The questionnaire was consisted of 28 questions where 11 questions were asked to identify sleep disturbance and different psychological states like anxiety and depression of the respondents. Several questions were asked to identify respondent's caffeine and nicotine intake characteristics and self-medication practice to overcome their sleep disturbance and other psychological stresses during the COVID-19 pandemic. Rest of the questions were related to their socio-demographic characteristics.

Data validation: Before starting the survey, the participant's response data were validated by finding internal consistency reliability using Cronbach's alpha $(\alpha)$ and intra-class correlation coefficient. Three weeks before starting the original survey, a pilot survey was conducted among 63 respondents which were excluded from the final survey. The Cronbach's alpha and intra-class correlation coefficient were found 0.78 and 0.92 respectively. Both results had indicated acceptability and excellent internal consistency reliability of data. ${ }^{21}$

Determination of sample size: This study was conducted among the general populace of Bangladesh. The current total population of Bangladesh is more than 160 million. ${ }^{22}$ The sample size was of the study was calculated by Rasoft $_{\circledast}$. The minimum estimated sample size would be 385 where the confidence level was $95 \%$. As the total number of respondents was 2941, the sample size was more than the minimum estimated value which fulfilled the study requirement. ${ }^{23}$

Statistical analysis: Microsoft Excel 2019 and Statistical Package for Social Sciences (IBM SPSS version 22) were used for statistical analysis. Firstly, responses were converted from Google Form to Google Sheet. Then the data were imported to Microsoft Excel. Microsoft Excel was used for data sorting, coding and editing. The excel file was imported to the SPSS software and revealed in frequencies, means and percentage. Moreover, Pearson's chi-square $\left(\chi^{2}\right)$ statistic was performed among the categorical coded variables to identify the association between dependent and independent variables as well as Spearman's rank correlation coefficient was calculated for checking the strength of the correlated variables.

Ethical statement: The research was conducted by following the declaration of Helsinki though it was only a questionnaire-based survey which was not doing any harm to any human or animal or not related to any clinical trial. Moreover, consent was taken from each respondent before participating in the survey. However, a permission was taken from the Chairman, Department of Pharmacy, Faculty of Pharmacy, University of Dhaka before starting the survey.

\section{Results}

Five socio-demographic characteristics, i.e., age, gender, current residence, profession and educational qualification of the respondents were taken into consideration in this study. All of the variables were categorically coded. The survey had a total of 2941 respondents where $63.28 \%$ of them were male and $36.65 \%$ were female. The respondents were categorized into several groups on the basis of their age, with the majority $(68.3 \%)$ belonging to the age group 16-25 years. Most of the respondents $(76.9 \%)$ reported themselves to be urbanites and the rest (23.1\%) were from rural areas. The data analysis revealed that $66.4 \%$ of the respondents were students, most belonging to the undergraduate level $(40.9 \%)$. As the survey was conducted online through social media, the results portrayed that the engagement of the urban youth in online social media during the COVID-19 pandemic was greater than that of other socio-demographic classes. These results are illustrated in Table 1.

In this study, sleep quality and psychosocial state of Bangladeshi population during the COVID-19 pandemic were evaluated. The participants filled out a self-reported questionnaire comprised of structured questions regarding several psychosocial parameters like sleep disturbance, anxiety and depression. The responses are illustrated in Table 2.

Initially, the association of different socio-demographic characteristics with sleep quality and psychosocial states during the COVID-19 pandemic were analyzed. Since all of the variables were categorical and coded, the chi-square $\left(\chi^{2}\right)$ statistic was used for checking association and spearman rank correlation coefficient was calculated for checking the strength of the correlated variables. The sections on sleep disturbance (comprised of 7 questions), anxiety (comprised of 2 questions) and depression (comprised of 2 questions) were considered for primary analysis.

Analysis revealed that the age variable was significant $(\mathrm{p}<0.05)$ with noticeability of sleep problems, worry about sleep problems, sleep problems interfering with daily functions, difficulty in falling asleep, difficulty staying asleep, problems waking up too early at $5 \%$ level of significance. However, the association between the age variable and the degree of satisfaction with sleep pattern was found to be statistically insignificant at $5 \%$ level of significance as the p-value was 0.055 $(>0.05)$, but it was significant at $10 \%$ level of significance. To simplify, all parameters of sleep disturbance were found to be associated with the age variable at $5 \%$ level of significance except the degree of satisfaction with sleep pattern. After that, the associations between the gender variable and the parameters of sleep disturbance were found to be significant at $5 \%$ level of significance, with the results indicating a high level of association. On the other hand, the current residence variable was found to be insignificant ( $\mathrm{p}=0.117$ ) with the problem of waking up too early and significant with the rest of the variables of sleep disturbance at $5 \%$ level of significance (Table 3 ).

The variables (profession, educational qualification and current residency) were found to be insignificantly associated to the problem of waking up too early, with respective $p$ values of $0.066,0.189$ and 0.117 respectively. Lack of association between the profession variable and difficulty staying asleep was also observed to a considerable degree, with a $p$ value of 0.554 . The three variables were found to be significantly associated with the rest of the parameters of sleep disturbance (Table 3).

The two variables regarding anxiety i.e. feeling nervous, anxious or on edge and inability to stop or control worrying, were significantly associated with all of the predefined socio-demographic characteristics at $5 \%$ level of significance, each having $\mathrm{p}$ values smaller than 0.05 . Significant association was also found between the two variables for estimating depression (namely little interest or pleasure in doing things and feeling down, depressed or hopeless) and all of the sociodemographic characteristics.

Each and every variable concerning sleep disturbance, anxiety and depression was found to be positively correlated with gender and profession but negatively correlated with current residence (Table 3). Variables, age and educational qualification, displayed positive correlations with the sleep parameter difficulty staying asleep but negative correlations with the rest. Table 3 also illustrated that variables age, gender, profession and educational qualification were highly correlated with the parameters of depression as Spearman rank correlation 
Table 3

Association and strength between socio-demographic characteristics and the sleep quality, psychosocial states during COVID-19 pandemic.

\begin{tabular}{|c|c|c|c|c|c|c|c|c|c|c|c|c|}
\hline \multirow{3}{*}{$\begin{array}{l}\text { Socio- } \\
\text { demographic } \\
\text { characteristic }\end{array}$} & \multirow{3}{*}{$\begin{array}{l}\text { Statistical } \\
\text { tools and } \\
\text { results }\end{array}$} & \multicolumn{11}{|c|}{ Sleep quality and psychosocial states } \\
\hline & & \multicolumn{7}{|c|}{ Sleep Disturbance } & \multicolumn{2}{|l|}{ Anxiety } & \multicolumn{2}{|l|}{ Depression } \\
\hline & & $\begin{array}{l}\text { Satisfied or } \\
\text { dissatisfied } \\
\text { with sleep } \\
\text { pattern during } \\
\text { the pandemic }\end{array}$ & $\begin{array}{l}\text { Noticeability to } \\
\text { others about your } \\
\text { sleep problem } \\
\text { during the } \\
\text { pandemic } \\
\text { in terms of } \\
\text { impairing the } \\
\text { quality of your life }\end{array}$ & $\begin{array}{l}\text { Worry about } \\
\text { sleep } \\
\text { problems } \\
\text { during the } \\
\text { pandemic }\end{array}$ & $\begin{array}{l}\text { Extent of sleep problem } \\
\text { interfering daily functioning } \\
\text { during the pandemic (e.g. } \\
\text { daytime fatigue, mood, } \\
\text { ability to function at work/ } \\
\text { daily chores, concentration, } \\
\text { memory, mood, etc.) }\end{array}$ & $\begin{array}{l}\text { Difficulty } \\
\text { in falling } \\
\text { asleep }\end{array}$ & $\begin{array}{l}\text { Difficulty } \\
\text { staying } \\
\text { asleep }\end{array}$ & $\begin{array}{l}\text { Problems } \\
\text { waking up } \\
\text { too early }\end{array}$ & $\begin{array}{l}\text { Feeling } \\
\text { nervous, } \\
\text { anxious or } \\
\text { on edge }\end{array}$ & $\begin{array}{l}\text { Not being } \\
\text { able to stop } \\
\text { or control } \\
\text { worrying }\end{array}$ & $\begin{array}{l}\text { Little } \\
\text { interest or } \\
\text { pleasure in } \\
\text { doing } \\
\text { things }\end{array}$ & $\begin{array}{l}\text { Feeling } \\
\text { down, } \\
\text { depressed or } \\
\text { hopeless }\end{array}$ \\
\hline \multirow[t]{4}{*}{ Age } & $\begin{array}{l}\text { Spearman } \\
\text { Rank } \\
\text { Correlation } \\
\text { coefficient(r) }\end{array}$ & -0.062 & -0.106 & -0.102 & -0.143 & -0.092 & 0.003 & -0.021 & -0.101 & -0.08 & -0.199 & -0.206 \\
\hline & $\chi^{2}$-Statistic & 36.004 & 48.818 & 40.552 & 70.279 & 43.437 & 54.383 & 38.308 & 50.983 & 34.045 & 134.74 & 146.679 \\
\hline & df & 24 & 18 & 18 & 18 & 24 & 24 & 24 & 18 & 18 & 18 & 18 \\
\hline & $\mathrm{p}$-value & $0.055^{\mathrm{b}}$ & $0.000^{\mathrm{a}}$ & $0.002^{\mathrm{a}}$ & $0.000^{\mathrm{a}}$ & $0.009^{\mathrm{a}}$ & $0.000^{\mathrm{a}}$ & $0.032^{\mathrm{a}}$ & $0^{\mathrm{a}}$ & $0.012^{\mathrm{a}}$ & $0.000^{\mathrm{a}}$ & $0.000^{\mathrm{a}}$ \\
\hline \multirow[t]{4}{*}{ Gender } & $\begin{array}{l}\text { Spearman } \\
\text { Rank } \\
\text { Correlation } \\
\text { coefficient(r) }\end{array}$ & 0.177 & 0.149 & 0.176 & 0.203 & 0.171 & 0.139 & 0.085 & 0.192 & 0.163 & 0.24 & 0.215 \\
\hline & $\chi^{2}-$ Statistic & 102.64 & 70.256 & 93.243 & 127.935 & 96.548 & 78.98 & 35.875 & 112.834 & 84.363 & 176.766 & 161.416 \\
\hline & df & 8 & 6 & 6 & 6 & 8 & 8 & 8 & 6 & 6 & 6 & 6 \\
\hline & $\mathrm{p}$-value & $0.000^{\mathrm{a}}$ & $0.000^{\mathrm{a}}$ & $0.000^{\mathrm{a}}$ & $0.000^{\mathrm{a}}$ & $0.000^{\mathrm{a}}$ & $0.000^{\mathrm{a}}$ & $0.000^{\mathrm{a}}$ & $0.000^{\mathrm{a}}$ & $0.000^{\mathrm{a}}$ & $0.000^{\mathrm{a}}$ & $0.000^{\mathrm{a}}$ \\
\hline \multirow[t]{4}{*}{$\begin{array}{l}\text { Current } \\
\text { residence }\end{array}$} & $\begin{array}{l}\text { Spearman } \\
\text { Rank } \\
\text { Correlation } \\
\text { coefficient(r) }\end{array}$ & -0.77 & -0.55 & -0.09 & -0.1 & -0.104 & -0.057 & -0.043 & -0.045 & -0.055 & -0.069 & -0.05 \\
\hline & $\chi^{2}$ - Statistic & 25.04 & 11.831 & 24.313 & 40.278 & 33.121 & 16.18 & 7.389 & 13.815 & 10.312 & 15.945 & 11.652 \\
\hline & $\mathrm{df}$ & 4 & 3 & 3 & 3 & 4 & 4 & 4 & 3 & 3 & 3 & 3 \\
\hline & $\mathrm{p}$-value & $0.000^{\mathrm{a}}$ & $0.008^{\mathrm{a}}$ & $0.000^{\mathrm{a}}$ & $0.000^{\mathrm{a}}$ & $0.000^{\mathrm{a}}$ & $0.003^{a}$ & 0.117 & $0.003^{\mathrm{a}}$ & $0.016^{\mathrm{a}}$ & $0.001^{\mathrm{a}}$ & $0.009^{\mathrm{a}}$ \\
\hline \multirow[t]{4}{*}{ Profession } & $\begin{array}{l}\text { Spearman } \\
\text { Rank } \\
\text { Correlation } \\
\text { coefficient(r) }\end{array}$ & 0.035 & 0.055 & 0.051 & 0.04 & 0.062 & 0.025 & 0.022 & 0.056 & 0.027 & 0.082 & 0.091 \\
\hline & $\chi^{2}$ - Statistic & 50.611 & 68.255 & 50.184 & 90.797 & 63.189 & 22.423 & 35.135 & 69.649 & 48.733 & 170.165 & 154.14 \\
\hline & $\mathrm{df}$ & 24 & 18 & 18 & 18 & 24 & 24 & 24 & 18 & 18 & & \\
\hline & $\mathrm{p}$-value & $0.001^{\mathrm{a}}$ & $0.000^{\mathrm{a}}$ & $0.000^{\mathrm{a}}$ & $0.000^{\mathrm{a}}$ & $0.000^{\mathrm{a}}$ & 0.554 & $0.066^{\mathrm{b}}$ & $0.000^{\mathrm{a}}$ & $0.000^{\mathrm{a}}$ & $0.000^{\mathrm{a}}$ & $0.000^{\mathrm{a}}$ \\
\hline \multirow[t]{4}{*}{$\begin{array}{l}\text { Educational } \\
\text { Qualification }\end{array}$} & $\begin{array}{l}\text { Spearman } \\
\text { Rank } \\
\text { Correlation } \\
\text { coefficient(r) }\end{array}$ & -0.073 & -0.121 & -0.093 & -0.115 & -0.069 & 0.021 & -0.027 & -0.038 & -0.021 & -0.132 & -0.153 \\
\hline & $\chi^{2}$-Statistic & 50.871 & 71.21 & 58.172 & 70.123 & 58.328 & 53.377 & 38.842 & 33.201 & 43.324 & 93.643 & 120.22 \\
\hline & & 32 & 24 & & 24 & 32 & 32 & 32 & 24 & 24 & & \\
\hline & p-value & $0.018^{\mathrm{a}}$ & $0.000^{\mathrm{a}}$ & $0.000^{\mathrm{a}}$ & $0.000^{\mathrm{a}}$ & $0.005^{\mathrm{a}}$ & $0.01^{\mathrm{a}}$ & 0.189 & 0.1 & $0.009^{\mathrm{a}}$ & $0.000^{\mathrm{a}}$ & $0.000^{\mathrm{a}}$ \\
\hline
\end{tabular}

${ }^{a}$ Significant at $5 \%$ level of significance $(\mathrm{p}<0.05)$

b Significant at $10 \%$ level of significance. 
Table 4

Association between sleep quality, psychosocial states and caffeine/nicotine intake during COVID-19 pandemic.

\begin{tabular}{|c|c|c|c|c|c|}
\hline \multirow{2}{*}{$\begin{array}{l}\text { Sleep quality } \\
\text { and } \\
\text { psychosocial } \\
\text { states }\end{array}$} & \multirow[t]{2}{*}{ Topics } & \multicolumn{2}{|c|}{ Caffeine intake } & \multicolumn{2}{|c|}{ Nicotine intake } \\
\hline & & $\begin{array}{l}\chi^{2}- \\
\text { Statistic }\end{array}$ & $\begin{array}{l}\mathrm{p}- \\
\text { value }\end{array}$ & $\begin{array}{l}\chi^{2}- \\
\text { Statistic }\end{array}$ & p-value \\
\hline \multirow[t]{7}{*}{$\begin{array}{l}\text { Sleep } \\
\text { disturbance }\end{array}$} & $\begin{array}{l}\text { Satisfied or } \\
\text { dissatisfied with } \\
\text { sleep pattern } \\
\text { during the } \\
\text { pandemic }\end{array}$ & 42.282 & $0.000^{\mathrm{a}}$ & 34.042 & $0.001^{\mathrm{a}}$ \\
\hline & $\begin{array}{l}\text { Noticeability to } \\
\text { others about your } \\
\text { sleep problem } \\
\text { during the } \\
\text { pandemic in terms } \\
\text { of impairing the } \\
\text { quality of your life }\end{array}$ & 30.746 & $0.000^{\mathrm{a}}$ & 24.388 & $0.004^{\mathrm{a}}$ \\
\hline & $\begin{array}{l}\text { Worry about sleep } \\
\text { problem during the } \\
\text { pandemic }\end{array}$ & 47.088 & $0.000^{\mathrm{a}}$ & 45.293 & $0.000^{\mathrm{a}}$ \\
\hline & $\begin{array}{l}\text { Extent of sleep } \\
\text { problem } \\
\text { interfering daily } \\
\text { functioning during } \\
\text { the pandemic (e.g. } \\
\text { daytime fatigue, } \\
\text { mood, ability to } \\
\text { function at work/ } \\
\text { daily chores, } \\
\text { concentration, } \\
\text { memory, mood, } \\
\text { etc.) }\end{array}$ & 54.134 & $0.000^{\mathrm{a}}$ & 39.179 & $0.000^{\mathrm{a}}$ \\
\hline & $\begin{array}{l}\text { Difficulty in falling } \\
\text { asleep }\end{array}$ & 61.761 & $0.000^{\mathrm{a}}$ & 31.082 & $0.002^{\mathrm{a}}$ \\
\hline & $\begin{array}{l}\text { Difficulty staying } \\
\text { asleep }\end{array}$ & 41.217 & $0.000^{\mathrm{a}}$ & 20.200 & $0.063^{* *}$ \\
\hline & $\begin{array}{l}\text { Problems waking } \\
\text { up too early }\end{array}$ & 34.181 & $0.001^{\mathrm{a}}$ & 12.493 & 0.407 \\
\hline \multirow[t]{2}{*}{ Anxiety } & $\begin{array}{l}\text { Feeling nervous, } \\
\text { anxious or on edge }\end{array}$ & 57.390 & $0.000^{\mathrm{a}}$ & 39.325 & $0.000^{\mathrm{a}}$ \\
\hline & $\begin{array}{l}\text { Not being able to } \\
\text { stop or control } \\
\text { worrying }\end{array}$ & 48.884 & $0.000^{\mathrm{a}}$ & 34.424 & $0.000^{\mathrm{a}}$ \\
\hline \multirow[t]{2}{*}{ Depression } & $\begin{array}{l}\text { Little interest or } \\
\text { pleasure in doing } \\
\text { things }\end{array}$ & 23.561 & $0.001^{\mathrm{a}}$ & 46.111 & $0.000^{\mathrm{a}}$ \\
\hline & $\begin{array}{l}\text { Feeling down, } \\
\text { depressed or } \\
\text { hopeless }\end{array}$ & 19.766 & $0.003^{\mathrm{a}}$ & 21.973 & 0.009 \\
\hline
\end{tabular}

a Significant at $5 \%$ level of significance $(\mathrm{p}<0.05)$. coefficient values were $-0.199 \&-0.206 ; 0.24 \& 0.215 ; 0.082 \& 0.091$; and $-0.132 \&-0.153$ respectively, whereas current residence was slightly correlated with anxiety and depression parameters but highly correlated $(r=-0.77)$ with level of satisfaction with sleep pattern of respondents during the pandemic.

The association between sleep quality, psychosocial states and caffeine/nicotine intake during the COVID-19 pandemic was analyzed using chi-square $(\chi)$ statistic. Seven variables were considered as parameters for sleep quality, and two variables were considered for anxiety and depression each. According to the analysis, the variable caffeine intake during the pandemic was found to significantly associated to all parameters of sleep quality, anxiety and depression, yielding $\mathrm{p}$ values lower than 0.005 in all cases. The associations between the variables, nicotine intake and the parameters of sleep quality were found significant at 5\% level of significance in all cases except for the variables, difficulty staying asleep and problems waking up too early, in case of which 0.063 and 0.407 were obtained as $p$ values respectively. It was evident from the analysis that caffeine intake had an effect of every parameter of sleep quality, anxiety and depression considered in this study; and that the aforementioned parameters, except difficulty staying asleep and problems waking up too early, were also affected by nicotine intake (Table 4).

Chi-square $\left(\chi^{2}\right)$ statistic was also used to analyze the associations between the parameters of sleep quality, anxiety and depression and the variables of electronic device usage and social media usage during the Covid-19 pandemic. Sleep quality, anxiety and depression were parameterized using 7, 2 and 2 variables respectively. In every case, the associations between the two groups of variables (the parameters of sleep quality, anxiety and depression; electronic device usage and social media usage) were found to be statistically significant, with every analysis yielding a p value lower than 0.005 , as is illustrated on Table 5 . Electronic device usage and social media usage during the pandemic should therefore be considered as contributing factors for sleep quality, anxiety and depression.

Among the total respondents $(\mathrm{n}=2941), 210$ (7.14\%) respondents reported that they had taken medicine without any doctor's prescription to overcome the sleep disturbances, anxiety or depression during the pandemic. On the basis of different socio-demographic characteristics, age groups above 35 years displayed a greater tendency to self-medicate whereas female $(8.63 \%)$ respondents were more frequent to take selfmedication than their male $(6.29 \%)$ equivalents. All the analysis results are illustrated in Table 6.

Administration (self or otherwise) of sedatives, anxiolytics and antidepressant drugs without a doctor's prescription is legally prohibited. Prolonged use of these drugs without proper prescription and supervision can induce drug dependency. As a considerable number of

Table 5

Association between sleep quality, psychosocial states and recreational activity factors during COVID-19 pandemic.

\begin{tabular}{|c|c|c|c|c|c|}
\hline \multicolumn{2}{|c|}{ Sleep quality and psychosocial states } & \multicolumn{2}{|c|}{$\begin{array}{l}\text { Electronic device } \\
\text { usage }\end{array}$} & \multicolumn{2}{|c|}{ Social media usage } \\
\hline & & $\begin{array}{l}\chi^{2}- \\
\text { Statistic }\end{array}$ & $\begin{array}{l}\text { p- } \\
\text { value }\end{array}$ & $\begin{array}{l}\chi^{2}- \\
\text { Statistic }\end{array}$ & $\begin{array}{l}\mathrm{p}- \\
\text { value }\end{array}$ \\
\hline \multirow{7}{*}{$\begin{array}{l}\text { Sleep } \\
\text { disturbance }\end{array}$} & Satisfied or dissatisfied with sleep pattern during the pandemic & 154.046 & $0.000^{\mathrm{a}}$ & 80.506 & $0.000^{\mathrm{a}}$ \\
\hline & $\begin{array}{l}\text { Noticeability to others about your sleep problem during the pandemic in terms of impairing the quality of your } \\
\text { life }\end{array}$ & 129.657 & $0.000^{\mathrm{a}}$ & 118.276 & $0.000^{\mathrm{a}}$ \\
\hline & Worry about sleep problem during the pandemic & 97.971 & $0.000^{\mathrm{a}}$ & 98.236 & $0.000^{\mathrm{a}}$ \\
\hline & $\begin{array}{l}\text { Extent of sleep problem interfering daily functioning during the pandemic (e.g. daytime fatigue, mood, ability } \\
\text { to function at work/daily chores, concentration, memory, mood, etc.) }\end{array}$ & 194.444 & $0.000^{\mathrm{a}}$ & 163.213 & $0.000^{\mathrm{a}}$ \\
\hline & Difficulty in falling asleep & 223.377 & $0.000^{\mathrm{a}}$ & 143.149 & $0.000^{\mathrm{a}}$ \\
\hline & Difficulty staying asleep & 79.044 & $0.000^{\mathrm{a}}$ & 74.991 & $0.000^{\mathrm{a}}$ \\
\hline & Problems waking up too early & 67.472 & $0.000^{\mathrm{a}}$ & 61.092 & $0.000^{\mathrm{a}}$ \\
\hline \multirow[t]{2}{*}{ Anxiety } & Feeling nervous, anxious or on edge & 104.235 & $0.000^{\mathrm{a}}$ & 145.324 & $0.000^{\mathrm{a}}$ \\
\hline & Not being able to stop or control worrying & 102.693 & $0.000^{\mathrm{a}}$ & 141.095 & $0.000^{\mathrm{a}}$ \\
\hline \multirow[t]{2}{*}{ Depression } & Little interest or pleasure in doing things & 243.298 & $0.000^{\mathrm{a}}$ & 194.116 & $0.000^{\mathrm{a}}$ \\
\hline & Feeling down, depressed or hopeless & 205.904 & $0.000^{\mathrm{a}}$ & 254.929 & $0.000^{\mathrm{a}}$ \\
\hline
\end{tabular}

a Significant at $5 \%$ level of significance $(\mathrm{p}<0.05)$. 
Table 6

Self-medication practice of sleep aids among the respondents to overcome sleep disturbance, anxiety and depression during the pandemic $(\mathrm{n}=2941)$.

\begin{tabular}{|c|c|c|c|c|}
\hline \multicolumn{2}{|c|}{ Socio-demographic characteristics } & \multicolumn{3}{|c|}{$\begin{array}{l}\text { Have you taken any medicine without } \\
\text { doctor's prescription to overcome sleep } \\
\text { disturbance, anxiety and depression? }(\%)\end{array}$} \\
\hline & & $\begin{array}{l}\text { Number of } \\
\text { responses }\end{array}$ & Yes & No \\
\hline \multirow[t]{7}{*}{ Age } & $\leq 15$ & $21(100 \%)$ & $1(4.76 \%)$ & $\begin{array}{l}20 \\
(95.24 \%)\end{array}$ \\
\hline & $16-25$ & $\begin{array}{l}2009 \\
(100 \%)\end{array}$ & $\begin{array}{l}125 \\
(6.22 \%)\end{array}$ & $\begin{array}{l}1884 \\
(93.78 \%)\end{array}$ \\
\hline & $26-35$ & $730(100 \%)$ & $\begin{array}{l}56 \\
(7.67 \%)\end{array}$ & $\begin{array}{l}674 \\
(92.33 \%)\end{array}$ \\
\hline & $36-45$ & $122(100 \%)$ & $\begin{array}{l}17 \\
(13.93 \%)\end{array}$ & $\begin{array}{l}105 \\
(86.07 \%)\end{array}$ \\
\hline & $46-55$ & $35(100 \%)$ & $\begin{array}{l}6 \\
(17.14 \%)\end{array}$ & $\begin{array}{l}29 \\
(82.86 \%)\end{array}$ \\
\hline & $56-65$ & $22(100 \%)$ & $\begin{array}{l}5 \\
(22.73 \%)\end{array}$ & $\begin{array}{l}17 \\
(77.27 \%)\end{array}$ \\
\hline & $\geq 66$ & $2(100 \%)$ & $0(0.00 \%)$ & $2(100 \%)$ \\
\hline \multirow[t]{3}{*}{ Gender } & Male & $\begin{array}{l}1861 \\
(100 \%)\end{array}$ & $\begin{array}{l}117 \\
(6.29 \%)\end{array}$ & $\begin{array}{l}1744 \\
(93.71 \%)\end{array}$ \\
\hline & Female & $\begin{array}{l}1078 \\
(100 \%)\end{array}$ & $\begin{array}{l}93 \\
(8.63 \%)\end{array}$ & $\begin{array}{l}985 \\
(91.37 \%)\end{array}$ \\
\hline & Prefer not to say & $2(100 \%)$ & $0(0.00)$ & $2(100 \%)$ \\
\hline \multirow[t]{2}{*}{$\begin{array}{l}\text { Current } \\
\text { Residence }\end{array}$} & Urban & $\begin{array}{l}2262 \\
(100 \%)\end{array}$ & $\begin{array}{l}174 \\
(7.69 \%)\end{array}$ & $\begin{array}{l}2088 \\
(92.31 \%)\end{array}$ \\
\hline & Rural & $679(100 \%)$ & $\begin{array}{l}36 \\
(5.30 \%)\end{array}$ & $\begin{array}{l}643 \\
(94.70 \%)\end{array}$ \\
\hline \multirow[t]{7}{*}{ Profession } & $\begin{array}{l}\text { Government } \\
\text { Employee }\end{array}$ & $138(100 \%)$ & $\begin{array}{l}14 \\
(10.14 \%)\end{array}$ & $\begin{array}{l}124 \\
(89.86 \%)\end{array}$ \\
\hline & $\begin{array}{l}\text { Non-government } \\
\text { employee }\end{array}$ & $371(100 \%)$ & $\begin{array}{l}27 \\
(7.28 \%)\end{array}$ & $\begin{array}{l}344 \\
(92.72 \%)\end{array}$ \\
\hline & Teaching & $94(100 \%)$ & $\begin{array}{l}13 \\
(13.83 \%)\end{array}$ & $\begin{array}{l}81 \\
(86.17 \%)\end{array}$ \\
\hline & Banker & $46(100 \%)$ & $3(6.52 \%)$ & $\begin{array}{l}43 \\
(93.48 \%)\end{array}$ \\
\hline & Student & $\begin{array}{l}1953 \\
(100 \%)\end{array}$ & $\begin{array}{l}123 \\
(6.30 \%)\end{array}$ & $\begin{array}{l}1830 \\
(93.70 \%)\end{array}$ \\
\hline & Business person & $123(100 \%)$ & $3(2.44 \%)$ & $\begin{array}{l}120 \\
(97.56 \%)\end{array}$ \\
\hline & Others & $216(100 \%)$ & $\begin{array}{l}27 \\
(12.50 \%)\end{array}$ & $\begin{array}{l}189 \\
(87.50 \%)\end{array}$ \\
\hline \multirow[t]{7}{*}{$\begin{array}{l}\text { Educational } \\
\text { Qualification }\end{array}$} & Secondary & $205(100 \%)$ & $\begin{array}{l}17 \\
(8.29 \%)\end{array}$ & $\begin{array}{l}188 \\
(91.71 \%)\end{array}$ \\
\hline & Higher secondary & $453(100 \%)$ & $\begin{array}{l}22 \\
(4.86 \%)\end{array}$ & $\begin{array}{l}431 \\
(95.14 \%)\end{array}$ \\
\hline & Undergraduate & $\begin{array}{l}1203 \\
(100 \%)\end{array}$ & $\begin{array}{l}75 \\
(6.23 \%)\end{array}$ & $\begin{array}{l}1128 \\
(93.77 \%)\end{array}$ \\
\hline & Graduate & $473(100 \%)$ & $\begin{array}{l}32 \\
(6.77 \%)\end{array}$ & $\begin{array}{l}441 \\
(93.23 \%)\end{array}$ \\
\hline & Post-graduate & $528(100 \%)$ & $\begin{array}{l}49 \\
(9.28 \%)\end{array}$ & $\begin{array}{l}479 \\
(90.72 \%)\end{array}$ \\
\hline & M.Phil/PhD & $16(100 \%)$ & $\begin{array}{l}5 \\
(31.25 \%)\end{array}$ & $\begin{array}{l}11 \\
(68.75 \%)\end{array}$ \\
\hline & Others & $63(100 \%)$ & $\begin{array}{l}10 \\
(15.87 \%)\end{array}$ & $\begin{array}{l}53 \\
(84.13 \%)\end{array}$ \\
\hline
\end{tabular}

respondents of this survey were found to be taking these kinds of medications to overcome their sleep disturbance, anxiety and depression during the pandemic, several questions were included in the questionnaire to identify if any drug dependency had developed among the selfmedicated respondents. On the basis of socio-demographic characteristics, $4 \%, 3.57 \%$ and $5.88 \%$ respondents of the respective age groups 16-25, 26-35 and 36-45 had felt an extreme urge to take the selfmedicated drug again within last 30 days. $10.26 \%$ of all selfmedicated male respondents expressed a considerable or extreme urge to readminister their choice of psychotropics, while the percentage was only $8.6 \%$ among the female respondents. All these analyses are showed in Table 7.

However, $48.10 \%$ of self-medicating respondents claimed that they felt better physically and/or psychologically after self-medication, while the rest felt indifferent or worse. $43.20 \%, 57.14 \%$ and $47.06 \%$ respondents of age groups 16-25, 26-35 and 36-45 respectively had perceived desirable physical or psychological changes after selfmedication. A greater percentage of male (52.14\%) participants felt better after self-medication than the female (43.01\%) participants. These analyses are tabulated in Table 8 along with other sociodemographic characteristics.

\section{Discussion}

The study illustrated the prevalence of various physio-psychological problems of the participants. $10-29.5 \%$ reported experiencing sleepassociated problems to at least a considerable degree. Summing up the two least desirable ranges of data in Table 2, we saw that an almost equal portion of the participants expressed their dissatisfaction with sleep pattern during the pandemic (19.75\%) and stated that their sleep problems were considerably noticeable to others $(21.12 \%)$. However, only $17.23 \%$ were found to be substantially worried about their sleep problems, while a staggering $29.52 \%$ claimed that their sleep problems had a notable effect on their daily activities. On the other hand, smaller percentages of people reported having difficulties in falling asleep (12.1\%), staying asleep $(10.14 \%)$ or waking up too early $(13.84 \%)$. The variance in the data shows that while different sorts of sleep-associated problems have been persistent during the pandemic, the degree and extent to which they are experienced differ noticeably.

Moreover, $22.92 \%$ of the respondents reported feelings of nervousness or anxiety nearly every day, while $22.24 \%$ reported that they were unable to stop worrying. Both factors were considered signs of anxiety. The findings are consistent with Gualano et al. (2020), who reported that signs of anxiety were prominent in $23.2 \%$ of the respondents in an Italian regional study. ${ }^{24}$ In addition, $23.87 \%$ and $29.28 \%$ of respondents of our study expressed little interest or pleasure in doing things and felt depressed, down or hopeless nearly every day respectively. These results are pretty similar to Mazza et al. (2020) and Gualano et al. (2020) where the percentage of people suffering from depression were $32.4 \%$ and $24.7 \%$ respectively. ${ }^{24,33}$

The first five parameters of sleep quality were found to be associated with the socio-demographic variables gender, current residence, occupation, and educational qualification; with only the last two sleep quality parameters not being associated with some of the aforementioned socio-demographic variables. The variable age was found to be associated with all of the sleep quality parameters except for the first.

The associations between the five socio-demographic variables and factors concerning anxiety and depression reached significance in each case. Changes in all parameters of physio-psychological health (e.g. sleep quality, anxiety and depression) were found to be strongly associated with caffeine and nicotine intake during the pandemic. Our findings regarding nicotine intake are quite similar to those of Stanton et al. (2020) who found a clear connection between smoking and anxiety-depression during the pandemic. ${ }^{25}$ Similar strong associations were found with the aforementioned parameters and the variables electronic device usage and social media usage. Several recent studies have already addressed the increasing trends in electronic and social media usage and their association with health consequences during COVID-19. ${ }^{6,26-28}$ A survey conducted in China reported the association of increased screen time with changes in health behavior. ${ }^{26}$ Again, in a Polish study, $49 \%$ of participants found to have a prolonged screen time during the pandemic which is interpreted as a factor affecting the changes in dietary, lifestyle \& sedentary behavior of participants during the pandemic. ${ }^{27}$

The persistence of self-medication of sleep aids was a key focus in the current study. Using self-medicated sleep aids during the pandemic was reported by $7.14 \%$ of the population. Our data analysis showed that the elderly was more likely to self-medicate with psychotropic medications to handle pandemic related physio-psychological problems. These findings are similar to Simoni-Wastila et al. (2004) who reported that US citizens aged 35 years or older were more likely to non-medically use 
Table 7

Chance of drug dependency among the respondents $(n=210)$ after self-medication.

\begin{tabular}{|c|c|c|c|c|c|c|c|}
\hline \multicolumn{2}{|c|}{ Socio-demographic characteristics } & \multicolumn{6}{|c|}{ Have you ever felt the urge to take the self-medicated drugs again in the last 30 days? (\%) } \\
\hline & & \multirow{2}{*}{$\begin{array}{l}\text { Number of Responses } \\
1(100 \%)\end{array}$} & \multirow{2}{*}{$\frac{\text { Not at all }}{1(100 \%)}$} & \multirow{2}{*}{$\begin{array}{l}\text { Slightly } \\
0(0.00 \%)\end{array}$} & \multirow{2}{*}{$\begin{array}{l}\text { Moderately } \\
0(0.00 \%)\end{array}$} & \multirow{2}{*}{$\begin{array}{l}\text { Considerably } \\
0(0.00 \%)\end{array}$} & \multirow{2}{*}{$\begin{array}{l}\text { Extremely } \\
0(0.00 \%)\end{array}$} \\
\hline Age & $\leq 15$ & & & & & & \\
\hline & $16-25$ & $125(100 \%)$ & $62(49.6 \%)$ & $40(32 \%)$ & $14(11.2 \%)$ & $4(3.2)$ & $5(4 \%)$ \\
\hline & $26-35$ & $56(100 \%)$ & $26(46.43 \%)$ & $19(33.93 \%)$ & $4(7.14 \%)$ & $5(8.93 \%)$ & $2(3.57 \%)$ \\
\hline & $36-45$ & $17(100 \%)$ & $11(64.71 \%)$ & $3(17.65 \%)$ & $0(0.00 \%)$ & $2(11.76 \%)$ & $1(5.88 \%)$ \\
\hline & $46-55$ & $6(100 \%)$ & $4(66.67 \%)$ & $2(33.33 \%)$ & $0(0.00 \%)$ & $0(0.00 \%)$ & $0(0.00 \%)$ \\
\hline & $56-65$ & $5(100 \%)$ & $0(0.00 \%)$ & $3(60 \%)$ & $1(20 \%)$ & $1(20 \%)$ & $(0.00 \%)$ \\
\hline & $\geq 66$ & $0(0.00 \%)$ & $0(0.00 \%)$ & $0(0.00 \%)$ & $0(0.00 \%)$ & $0(0.00 \%)$ & $0(0.00 \%)$ \\
\hline \multirow[t]{3}{*}{ Gender } & Male & $117(100 \%)$ & $56(47.86 \%)$ & $38(32.48 \%)$ & $11(9.40 \%)$ & $8(6.84 \%)$ & $4(3.42 \%)$ \\
\hline & Female & $93(100 \%)$ & $48(51.61 \%)$ & $29(31.18 \%)$ & $8(8.60 \%)$ & $4(4.30 \%)$ & $4(4.30 \%)$ \\
\hline & Prefer not to say & $0(0.00 \%)$ & $0(0.00 \%)$ & $0(0.00 \%)$ & $0(0.00 \%)$ & $0(0.00 \%)$ & $0(0.00 \%)$ \\
\hline \multirow[t]{2}{*}{ Current Residence } & Urban & $174(100 \%)$ & $91(52.30 \%)$ & $49(28.16 \%)$ & $16(9.2 \%)$ & $11(6.32 \%)$ & $7(4.02 \%)$ \\
\hline & Rural & $36(100 \%)$ & $13(36.11 \%)$ & $18(50 \%)$ & $3(8.33 \%)$ & $1(2.78 \%)$ & $1(2.78 \%)$ \\
\hline \multirow[t]{7}{*}{ Profession } & Government Employee & $14(100 \%)$ & $5(35.71 \%)$ & $7(50 \%)$ & $1(7.14 \%)$ & $0(0.00 \%)$ & $1(7.14 \%)$ \\
\hline & Non-government employee & $27(100 \%)$ & $16(59.26 \%)$ & $7(25.93 \%)$ & $0(0.00 \%)$ & $3(11.11 \%)$ & $1(3.70 \%)$ \\
\hline & Teaching & $13(100 \%)$ & $6(46.15 \%)$ & $4(30.77 \%)$ & $0(0.00 \%)$ & $3(23.08 \%)$ & $0(0.00 \%)$ \\
\hline & Banker & $3(100 \%)$ & $1(33.33 \%)$ & $1(33.33 \%)$ & $1(33.33 \%)$ & $0(0.00 \%)$ & $0(0.00 \%)$ \\
\hline & Student & $123(100 \%)$ & $62(50.41 \%)$ & $37(30.08 \%)$ & $14(11.38 \%)$ & $6(4.88 \%)$ & $4(3.25 \%)$ \\
\hline & Business person & $3(100 \%)$ & $3(100 \%)$ & $0(0.00 \%)$ & $0(0.00 \%)$ & $0(0.00 \%)$ & $0(0.00 \%)$ \\
\hline & Others & $27(100 \%)$ & $11(40.74 \%)$ & $11(40.74 \%)$ & $3(11.11 \%)$ & $0(0.00 \%)$ & $2(7.41 \%)$ \\
\hline \multirow[t]{7}{*}{ Educational Qualification } & Secondary & $17(100 \%)$ & $12(70.59 \%)$ & $3(17.65 \%)$ & $2(11.76 \%)$ & $0(0.00 \%)$ & $0(0.00 \%)$ \\
\hline & Higher secondary & $22(100 \%)$ & $13(59.09 \%)$ & $7(31.82 \%)$ & $1(4.55 \%)$ & $1(4.55 \%)$ & $0(0.30 \%)$ \\
\hline & Undergraduate & $75(100 \%)$ & $33(44 \%)$ & $23(30.67 \%)$ & $9(12 \%)$ & $5(6.67 \%)$ & $5(6.67 \%)$ \\
\hline & Graduate & $32(100 \%)$ & $16(50 \%)$ & $12(37.5 \% \%)$ & $2(6.25 \%)$ & $1(3.125 \%)$ & $1(3.125 \%)$ \\
\hline & Post-graduate & 49 (100\%) & $24(48.98 \%)$ & 17 (34.69\%) & $2(4.08 \%)$ & $4(8.16 \%)$ & $2(4.08 \%)$ \\
\hline & M.Phil/PhD & $5(100 \%)$ & $1(20 \%)$ & $2(40 \%)$ & $1(20 \%))$ & $1(20 \%)$ & $0(0.00 \%)$ \\
\hline & Others & $10(100 \%)$ & $5(50 \%)$ & $3(30 \%)$ & $2(20 \%)$ & $0(0.00 \%)$ & $0(0.00 \%)$ \\
\hline
\end{tabular}

psychotropic. ${ }^{30}$ However, since this survey was conducted virtually, weighted data distribution was observed in terms of age, owing to the lack of elderly data. Hence, these results may not be a true representative of the actual population. Farther investigations regarding this issue can help clarify this.

Female respondents showed a slightly higher tendency to selfmedicate sleep aids compared to their male counterparts $(8.63 \%$ vs $6.29 \%$ ). This deduction is consistent with that of Beck et al. (2021), which found that the rate of hypnotic uptake was more prevalent in women relative to men. ${ }^{29}$ Simoni-Wastila et al. (2004) also declared gender as a risk factor for non-medical use of psychotropic and stated that non-medical use was more persistent among the female populaces. ${ }^{30}$ These authors found statistical significance between overall non-medical use of psychotropic and gender (female) and age (35 years or older), but statistical significance was not found concerning sedative-hypnotic use specifically. The socio-economic differences between the USA and Bangladesh may contribute to this inconsistency, as may the difference in levels of difficulty in obtaining controlled medication in the two countries. ${ }^{13,31}$ Self-medication of sleep aids was marginally more persistent in the urban participants as opposed to the rural participants.

The data analysis hinted at the possible development of drug dependency, as $18.57 \%$ of the self-medicating respondents reported moderate to extreme urges to self-medicate repeatedly, while $31.90 \%$ reported a slight urge. The male participants displayed a greater urge as opposed to their female counterparts, as did the urban respondents in contrast to the rural ones. Previous studies had demonstrated that the adult male populace was more likely to abuse illicit substances recurrently than adult females. ${ }^{32}$ A greater percentage of the male respondents also reported feeling better physically and/or psychologically after self-medication of psychotropic as contrasted with their female counterparts.

\section{Conclusion}

This survey study showed that a significant number of Bangladeshi populaces were suffering from psychological and sedentary issues during this COVID-19 crisis as for many other countries. These issues influenced a certain number of people towards the self-medication practice of sleep aids. Consequent signs of drug dependency were observed in a significant number of respondents which may result in further physical and psychological complications.

Since this survey was conducted online and lasted for only ten days, the data distribution was not consistent in all cases. Besides, a large portion of respondents were young population and they lived in urban areas. Therefore, some inferences may not be accurate representations of the whole pandemic period. Keep in mind the limitations, future studies will be designed for extended period so that the representativeness can be more accurate in terms of socio-demographic characteristics.

\section{Author statement}

K.M. Yasif Kayes Sikdar: Conceptualization, Methodology, Software, Validation, Formal analysis, Resources, Writing-review and editing, Supervision. Juhaer Anjum: Conceptualization, Methodology, Software, Formal analysis, Investigation, Resources, Data curation, Writing - original draft preparation. Nasiba Binte Bahar: Conceptualization, Investigation, Resources, Data curation, Writing — original draft preparation. Maniza Muni: Conceptualization, Investigation, Resources, Data curation, Writing - original draft preparation. S.M. Rakibul Hossain: Conceptualization, Investigation, Resources, Data curation, Writing —original draft preparation. Ashfia Tasnim Munia: Conceptualization, Methodology, Software, Validation, Formal analysis, Data curation, Writing-original draft preparation. A.S.M. Monjur AlHossain: Conceptualization, Validation, Writing-review and editing, Supervision.

\section{Declaration of competing interest}

The authors declare that they have no known competing financial interests or personal relationships that could have appeared to influence the work reported in this paper. 
Table 8

Perception of physio-psychological changes among the respondents $(n=210)$ after self-medication.

\begin{tabular}{|c|c|c|c|c|}
\hline \multicolumn{2}{|c|}{ Socio-demographic characteristics } & \multicolumn{3}{|c|}{$\begin{array}{l}\text { Have you felt better physically and/or } \\
\text { psychologically after taking self- } \\
\text { medication? }(\%)\end{array}$} \\
\hline & & $\begin{array}{l}\text { Number of } \\
\text { responses }\end{array}$ & Yes & No \\
\hline \multirow[t]{7}{*}{ Age } & $\leq 15$ & $1(100 \%)$ & $1(100 \%)$ & $0(0.00 \%)$ \\
\hline & $16-25$ & $125(100 \%)$ & $\begin{array}{l}54 \\
(43.20 \%)\end{array}$ & $\begin{array}{l}71 \\
(56.80 \%)\end{array}$ \\
\hline & $26-35$ & $56(100 \%)$ & $\begin{array}{l}32 \\
(57.14 \%)\end{array}$ & $\begin{array}{l}24 \\
(42.86 \%)\end{array}$ \\
\hline & $36-45$ & $17(100 \%)$ & $\begin{array}{l}8 \\
(47.06 \%)\end{array}$ & $\begin{array}{l}9 \\
(52.94 \%)\end{array}$ \\
\hline & $46-55$ & $6(100 \%)$ & $\begin{array}{l}4 \\
(66.67 \%)\end{array}$ & $\begin{array}{l}2 \\
(33.33 \%)\end{array}$ \\
\hline & $56-65$ & $5(100 \%)$ & $\begin{array}{l}2 \\
(40.00 \%)\end{array}$ & $\begin{array}{l}3 \\
(60.00 \%)\end{array}$ \\
\hline & $\geq 66$ & $0(0.00 \%)$ & $0(0.00 \%)$ & $0(0.00 \%)$ \\
\hline \multirow[t]{3}{*}{ Gender } & Male & $117(100 \%)$ & $\begin{array}{l}61 \\
(52.14 \%)\end{array}$ & $\begin{array}{l}56 \\
(47.86 \%)\end{array}$ \\
\hline & Female & $93(100 \%)$ & $\begin{array}{l}40 \\
(43.01 \%)\end{array}$ & $\begin{array}{l}53 \\
(56.99 \%)\end{array}$ \\
\hline & Prefer not to say & $0(0.00 \%)$ & $0(0.00 \%)$ & $0(0.00 \%)$ \\
\hline \multirow[t]{2}{*}{$\begin{array}{l}\text { Current } \\
\text { Residence }\end{array}$} & Urban & $174(100 \%)$ & $\begin{array}{l}81 \\
(46.55 \%)\end{array}$ & $\begin{array}{l}93 \\
(53.45 \%)\end{array}$ \\
\hline & Rural & $36(100 \%)$ & $\begin{array}{l}20 \\
(55.56 \%)\end{array}$ & $\begin{array}{l}16 \\
(44.44 \%)\end{array}$ \\
\hline \multirow[t]{7}{*}{ Profession } & $\begin{array}{l}\text { Government } \\
\text { Employee }\end{array}$ & $14(100 \%)$ & $\begin{array}{l}8 \\
(57.14 \%)\end{array}$ & $\begin{array}{l}6 \\
(42.86 \%)\end{array}$ \\
\hline & $\begin{array}{l}\text { Non-government } \\
\text { employee }\end{array}$ & $27(100 \%)$ & $\begin{array}{l}15 \\
(55.56 \%)\end{array}$ & $\begin{array}{l}12 \\
(44.44 \%)\end{array}$ \\
\hline & Teaching & $13(100 \%)$ & $\begin{array}{l}10 \\
(76.92 \%)\end{array}$ & $\begin{array}{l}3 \\
(23.08 \%)\end{array}$ \\
\hline & Banker & $3(100 \%)$ & $3(100 \%)$ & $0(0.00 \%)$ \\
\hline & Student & $123(100 \%)$ & $\begin{array}{l}53 \\
(43.09 \%)\end{array}$ & $\begin{array}{l}70 \\
(56.91 \%)\end{array}$ \\
\hline & Business person & $3(100 \%)$ & $\begin{array}{l}2 \\
(66.67 \%)\end{array}$ & $\begin{array}{l}1 \\
(33.33 \%)\end{array}$ \\
\hline & Others & $27(100 \%)$ & $\begin{array}{l}13 \\
(48.15 \%)\end{array}$ & $\begin{array}{l}14 \\
(51.85 \%)\end{array}$ \\
\hline \multirow[t]{7}{*}{$\begin{array}{l}\text { Educational } \\
\text { Qualification }\end{array}$} & Secondary & $17(100 \%)$ & $\begin{array}{l}8 \\
(47.06 \%)\end{array}$ & $\begin{array}{l}9 \\
(52.92 \%)\end{array}$ \\
\hline & Higher secondary & $22(100 \%)$ & $\begin{array}{l}7 \\
(31.82 \%)\end{array}$ & $\begin{array}{l}15 \\
(68.18 \%)\end{array}$ \\
\hline & Undergraduate & $75(100 \%)$ & $\begin{array}{l}33 \\
(44.00 \%)\end{array}$ & $\begin{array}{l}42 \\
(56.00 \%)\end{array}$ \\
\hline & Graduate & $32(100 \%)$ & $\begin{array}{l}18 \\
(56.25 \%)\end{array}$ & $\begin{array}{l}14 \\
(43.75 \%)\end{array}$ \\
\hline & Post-graduate & $49(100 \%)$ & $\begin{array}{l}25 \\
(51.02 \%)\end{array}$ & $\begin{array}{l}24 \\
(48.98 \%)\end{array}$ \\
\hline & M.Phil./PhD & $5(100 \%)$ & $\begin{array}{l}3 \\
(60.00 \%)\end{array}$ & $\begin{array}{l}2 \\
(40.00 \%)\end{array}$ \\
\hline & Others & $10(100 \%)$ & $\begin{array}{l}7 \\
(70.00 \%)\end{array}$ & $\begin{array}{l}3 \\
(30.00 \%)\end{array}$ \\
\hline
\end{tabular}

\section{References}

1 Worldometers. Coronavirus update. Accessed on https://www.worldometers. info/coronavirus/\#countries; 2021. Accessed May 1, 2021.

2 Yuan Z, Xiao Y, Dai Z, Huang J, Zhang Z, Chen Y. Modelling the effects of Wuhan's lockdown during COVID-19, China. Bull World Health Organ. 2020;98(7):484.

3 Anwar S, Nasrullah M, Hosen MJ. COVID-19 and Bangladesh: challenges and how to address them. Frontiers in public health. 2020;8.

4 Worldometers. BangladeshCoronavirus. Accessed on https://www.worldometers. info/coronavirus/country/bangladesh/; 2021. Accessed May 1, 2021.

5 Mucci F, Mucci N, Diolaiuti F. Lockdown and isolation: psychological aspects of COVID-19 pandemic in the general population. Clinical Neuropsychiatry. 2020;17(2): 63-64.

$6 \mathrm{Hu}$ Z, Lin X, Kaminga AC, Xu H. Impact of the COVID-19 epidemic on lifestyle behaviors and their association with subjective well-being among the general population in mainland China: cross-sectional study. J Med Internet Res. 2020;22(8), e21176.
7 Xiang M, Zhang Z, Kuwahara K. Impact of COVID-19 pandemic on children and adolescents' lifestyle behavior larger than expected. Progress in Cardiovascular Diseases. 2020.

8 Liang L, Gao T, Ren H, Cao R, Qin Z, Hu Y, Mei S. ? covid19? > Post-traumatic stress disorder and psychological distress in Chinese youths following the COVID-19 emergency. J Health Psychol. 2020;25(9):1164-1175.

9 Zhang C, Yang L, Liu S, Ma S, Wang Y, Cai Z, Zhang B. Survey of insomnia and related social psychological factors among medical staff involved in the 2019 novel coronavirus disease outbreak. Front Psychiatr. 2020;11:306.

10 Jamgade S, Joshi N. Physio-Psychological-Social and Financial Effect of COVID-19 on Hospitality Professionals. 2020.

11 Giri PA, Baviskar MP, Phalke DB. Study of sleep habits and sleep problems among medical students of Pravara Institute of Medical Sciences Loni, Western Maharashtra, India. Ann Med Health Sci Res. 2013;3(1):51-54.

12 Ara T, Rahman M, Hossain M, Ahmed A. Identifying the associated risk factors of sleep disturbance during the COVID-19 lockdown in Bangladesh: a web-based survey. Front Psychiatr. 2020;11:966.

13 Ahmed SM, Naher N, Hossain T, Rawal LB. Exploring the status of retail private drug shops in Bangladesh and action points for developing an accredited drug shop model: a facility based cross-sectional study. Journal of pharmaceutical policy and practice. 2017;10(1):1-12.

14 Almasdy D, Sharrif A. Self-medication practice with nonprescription medication among university students: a review of the literature. Arch Pharm Pract. 2011;2(3): 95.

15 Al-Faham Z, Habboub G, Takriti F. The sale of antibiotics without prescription in pharmacies in Damascus, Syria. The Journal of Infection in Developing Countries. 2011; 5:396-399, 05 .

16 Hale L, Guan S. Screen time and sleep among school-aged children and adolescents: a systematic literature review. Sleep Med Rev. 2015;21:50-58.

17 Levenson JC, Shensa A, Sidani JE, Colditz JB, Primack BA. The association between social media use and sleep disturbance among young adults. Prev Med. 2016;85: $36-41$.

18 Garett R, Liu S, Young SD. The relationship between social media use and sleep quality among undergraduate students. Inf Commun Soc. 2018;21(2):163-173.

19 Woods HC, Scott H. \# Sleepyteens: social media use in adolescence is associated with poor sleep quality, anxiety, depression and low self-esteem. $J$ Adolesc. 2016;51: 41-49.

20 Christensen MA, Bettencourt L, Kaye L, et al. Direct measurements of smartphone screen-time: relationships with demographics and sleep. PloS One. 2016;11(11), e0165331.

21 Munia AT, Sikdar KYK, Haque MA, Islam MA, Sarkar MR. Assessment of Bangladeshi People's knowledge, awareness, precautionary behavior and preventive actions during the COVID-19 pandemic: a cross-sectional survey. Malaysian Journal of Medicine and Health Sciences. 2021;17(2):225-233.

22 UN World Population Prospects. Revision)- United Nations Population Estimates and Projections; 2019. https://worldpopulationreview.com/countries/Bangladeshpopulation?fbclid=IwAR2hWQtjV2cX21sIJW1arFMbaZ24sSN0qbnQ0ADx8ZvIFh YRV8mTmt5pCH8. Accessed on 01 May, 2021.

23 Saqueeb N, Rahman MM, Munia AT, Rahman SA, Muhit MA, Sikdar KYK. A crosssectional study on prevalence of self-medication practice among the students of University of Dhaka. International Journal of Pharmaceutical Research. 2021;13(2).

24 Gualano MR, Lo Moro G, Voglino G, Bert F, Siliquini R. Effects of Covid-19 lockdown on mental health and sleep disturbances in Italy. Int J Environ Res Publ Health. 2020; 17(13):4779.

25 Stanton R, To QG, Khalesi S, et al. Depression, anxiety and stress during COVID-19: associations with changes in physical activity, sleep, tobacco and alcohol use in Australian adults. Int J Environ Res Publ Health. 2020;17(11):4065.

26 Keel PK, Gomez MM, Harris L, Kennedy GA, Ribeiro J, Joiner TE. Gaining "The Quarantine 15:" Perceived versus observed weight changes in college students in the wake of COVID-19. Int J Eat Disord. 2020;53(11):1801-1808.

27 Górnicka M, Drywień ME, Zielinska MA, Hamułka J. Dietary and lifestyle changes during COVID-19 and the subsequent lockdowns among Polish adults: a Crosssectional online survey PLifeCOVID-19 study. Nutrients. 2020;12(8):2324.

28 Hossain MT, Ahammed B, Chanda SK, Jahan N, Ela MZ, Islam MN. Social and electronic media exposure and generalized anxiety disorder among people during COVID-19 outbreak in Bangladesh: a preliminary observation. PloS One. 2020;15(9), e0238974.

29 Beck F, Léger D, Fressard L, Peretti-Watel P, Verger P, Coconel Group.. Covid-19 health crisis and lockdown associated with high level of sleep complaints and hypnotic uptake at the population level. J Sleep Res. 2021;30(1):e13119.

30 Simoni-Wastila L, Strickler G. Risk factors associated with problem use of prescription drugs. Am J Publ Health. 2004;94(2):266-268.

31 Drug Enforcement Administration. Title 21 United States Code (USC) Controlled Substances Act. 2010

32 Substance Abuse and Mental Health Services Administration. Results from the 2006 National Survey on Drug Use and Health: national findings. Rockville, MD: Office of Applied Studies; 2007. NSDUH Series H-32, DHHS Publication, No. SMA 07-4293.

33 Mazza C, Ricci E, Biondi S, et al. A nationwide survey of psychological distress among Italian people during the COVID-19 pandemic: immediate psychological responses and associated factors. Int J Environ Res Publ Health. 2020;17(9):3165. 